\title{
Effect of Organic Wastes and Incubation Periods on the Availability of Iron, Manganese, Copper and Zinc in a Calcareous Soil
}

\author{
Hager AL. Farhat, Magda A Hussien, Wafaa H. Mahmud and Hoda A Mahmoud \\ Soil and Agric. Chemistry Department, Faculty of Agriculture, (Saba Basha), Alexandaria \\ University \\ Corresponding author: Hager, e-mail: sirtgirl69@yahoo.com
}

\begin{abstract}
A calcareous soil incubation experiment for four tasting of 16 weeks was carried out to ascertain the effect of compost, olive waste and lemon waste, on the amounts of extractable iron, manganese, copper and zinc in a calcareous soil. The rates of organic materials added were $0,0.5,1.0,1.5$ and $2 \%$ of the air-dried soil on dry weigh. The periods of sampling affected soil $\mathrm{pH}$ and were the lowest $(\mathrm{pH}=7.32)$ was produced at the fourth time of sampling with olive waste. Decreasing $\mathrm{pH}$ values with increasing rate of applied organic waste were observed at each time of sampling and with increasing time of sampling. The compost gave the highest values of available $\mathrm{Fe}, \mathrm{Mn}$ and $\mathrm{Zn}$ at the fourth time of incubation $(5.41,22.04$ and $5.02 \mathrm{mg} / \mathrm{kg}$ soil, respectively), while, the olive waste gave the highest value of available $\mathrm{Cu}(5.11 \mathrm{mg} / \mathrm{kg}$ soil) at the fourth time of incubation. Generally, the available $\mathrm{Fe}, \mathrm{Cu}, \mathrm{Mn}$ and $\mathrm{Zn}$ were increased with increasing organic materials rate and increasing time of sampling. The highest values of available $\mathrm{Fe}(6.16 \mathrm{mg} / \mathrm{kg}$ soil), available $\mathrm{Zn}(6.21 \mathrm{mg} / \mathrm{kg}$ soil), available $\mathrm{Mn}(23.87 \mathrm{mg} / \mathrm{kg}$ soil) and available $\mathrm{Cu}(6.71 \mathrm{mg} / \mathrm{kg}$ soil) were recorded for $2 \%$ organic material application, rate at the fourth time of sampling.
\end{abstract}

Key words: Heavy metals, pH, DTPA- extractant, olive waste, lemon waste, compost

\section{INTRODUCTION}

Application of organic wastes as a source of organic matter is a common practice to improve soil properties (Baran, 2001). Land disposal of organic waste materials may directly or indirectly alter the trace element status of the soil by affecting elements solubility or dissociation kinetics (Del et al., 1993). Distribution of trace element between soil and solution is the key to evaluated the environmental impact of the metals. Despite the complexity of possible reaction, several important soil factors controlling the distribution of heavy metals between soil and solution have been identified (Sposito, 1989 and Temminghoff et al., 1998).

The effect of soil $\mathrm{pH}$ on soil solution concentrations and extractability of metals have been studied. He and Singh (1993) found that peat addition increased DTPA-extractable $\mathrm{Cd}$ in soil due to decrease in soil $\mathrm{pH}$ caused by peat application. Arnesen and Singh (1999) found that the lowing of $\mathrm{pH}$ in peatamended soil decreased the sorption of $\mathrm{Cd}, \mathrm{Cu}, \mathrm{Zn}$ and $\mathrm{Ni}$ in the soil. Organic matter makes strong complexes with heavy metals (Krogstad, 1983). The amount of organic matter in soils affects the binding of heavy metals in soil and speciation in soil solution (Lo et al., 1992). High organic matter content or addition of organic matter increases the extractability of $\mathrm{Zn}$ (Arnesen and Singh, 
1999). Amendment with organic matter and the resulting degradation may change the soil $\mathrm{pH}$ and thereby indirectly affect the bio-availability of metals. Many authors have found that all types of organic material increased the extractability of $\mathrm{Zn}$ in soil (Arnesen and Singh 1999). Also, Hossien, (2008) stated that the $\mathrm{pH}$ of treated soils with lemon waste was decreasesd slightly with increasing with the amount of lemon waste and time of sampling. Moreover, Gigliotti et al. (1996) observed significant increase with $\mathrm{Cu}, \mathrm{Zn}, \mathrm{Pb}$ and $\mathrm{Cr}$ concentrations in clay-loam calcareous soil amended with urban waste compost. Furthermore, Romero et al. (2005) found that the mount of soluble and AB-DTBA extractable $\mathrm{Pb}$ and $\mathrm{Zn}$ the mine tailing were increased by application of the olivemill solid waste and to a lesser degree, by the compost from the olive waste. Addionally, Hamidpour et al. (2012) in 3-years field study, conducted to assess effects of composted municipal waste on some properties, distribution of $\mathrm{Zn}, \mathrm{Cu}$ in a calcareous soil and uptake of these metals by wheat, showed that application of composted municipal waste decreased the soil $\mathrm{pH}$ and a significant increaseed the concentrations of $\mathrm{Zn}$ and $\mathrm{Cu}$ with increasing number and rate of compost application. Also, Bloomfileld and Pruden (1975) stated that the availability of $\mathrm{Cu}, \mathrm{Zn}, \mathrm{Mn}, \mathrm{Fe}$ and $\mathrm{P}$ in soils increased with increasing the applied amount of lemon waste and time of incubation.

The objective of this study was, therefore, to evaluate the effect of three organic materials (compost, olive waste and lemon waste) on the availability of $(\mathrm{Fe}, \mathrm{Mn}, \mathrm{Cu}$ and $\mathrm{Zn}$ ) as a function of $\mathrm{pH}$ in calcareous soil.

\section{MATERIALS AND METHODS}

The Used Soil and Organic Wastes: Soil was collected from surface horizon (0$30 \mathrm{~cm}$ ) from Matruh city at north western coast of Egypt. The soil was air-dried, ground and passed through a 2-mm sieve.

The tested organic materials were combost, olive waste and lemon waste which were ground and passed through $6.35 \mathrm{~mm}$ sieve. The main properties of the soil and the organic materials were determined according to the methods outlined by page et al. (1982). Some physical and chemical properties and the amounts of heavy metal of the sample and organic materials are given in Tables (1 and 2).

Incubation trial: The rates of organic material added the soil were $0,0.5,1.0$, 1.5 and $2 \%$ of the air-dried soil on dry weight basis. The soils were homogenized with the dry organic materials and filled in plastic pots $(4 \mathrm{~cm}$ deep and $10 \mathrm{~cm}$ diameter). Each pot consisted of $100 \mathrm{~g}$ soil with the various rate of organic materials. During the incubation periods $(4,8,12$ and 16 weeks) and the ambient temperature was 23 to $30 \mathrm{C}^{\circ}$ at the summer, the distilled water was added to each pot to keep the moisture content close to the filed capacity. Each treatment was repeated three times and the experimental layout was split plot design. Soil 
samples were taken on the $4^{\text {th }}\left(1^{\text {st }}\right.$ time $), 8^{\text {th }}\left(2^{\text {nd }}\right.$ time $) 12^{\text {th }}\left(3^{\text {rd }}\right.$ time $)$ and $16^{\text {th }}\left(4^{\text {th }}\right.$ time) weeks after incubation and analyzed for $\mathrm{pH}$ and DTPA extractable $\mathrm{Fe}, \mathrm{Mn}$, $\mathrm{Cu}$ and Zn. (Lindsay and Novvell, 1978).

Sample analysis: Soil $\mathrm{pH}$ and electrical conductivity (EC) was measured in 1:2, soil: water ratio according to Jackson (1973). Organic matter content in soil was determined by the method of Walkley and Black (Jakson, 1973). Particle size distribution was determined according the method outlined in Black (1965). Available $\mathrm{Fe}, \mathrm{Mn}, \mathrm{Cu}$ and $\mathrm{Zn}$ in soils were extracted with a DTPA method $(0.005$ $\mathrm{M}$ DTPA + 0.005M CaCl${ }_{2}+0.1 \mathrm{M}$ TEA, pH 7.3), according to Lindsay and Novvell, (1978). The organic materials were tested by digestion in $\mathrm{H}_{2} \mathrm{SO}_{4}$ and $\mathrm{H}_{2} \mathrm{O}_{2}$ (Lowther, 1980) for total heavy metals determination. The concentration of Fe, $\mathrm{Mn}, \mathrm{Cu}$ and $\mathrm{Zn}$ were measured by atomic absorption spectrophotometer (AAS).

The obtained data were statistically analyzed according to the technique of analysis of variance (ANOVA) and the least significant difference (L.S.D) was used to test the difference between the treatment means, as described by Gomez and Gomez (1984). 
Table (1): some physical and chemical properties of the used soil

\begin{tabular}{|c|c|}
\hline soil properties & means \\
\hline \multicolumn{2}{|c|}{ Particle size distribution (\%) } \\
\hline Clay & 25 \\
\hline Sand & 42 \\
\hline Silt & 33 \\
\hline Textural class & Loam \\
\hline$E C(d S / m) 1: 2$ & 0.29 \\
\hline pH 1:2 & 8.13 \\
\hline O.M (\%) & 1.30 \\
\hline $\mathrm{CaCO}_{3}(\%)$ & 25.4 \\
\hline \multicolumn{2}{|c|}{ Water Soluble anions $(\mathrm{mg} / \mathrm{kg})$} \\
\hline $\mathrm{HCO}_{3}^{-}$ & 5.600 \\
\hline $\mathrm{Cl}^{-}$ & 2.800 \\
\hline $\mathrm{SO}_{4}=$ & 0.029 \\
\hline \multicolumn{2}{|c|}{ Water Soluble cations (mg/kg) } \\
\hline $\mathrm{Na}^{+}$ & 14.0 \\
\hline $\mathrm{K}^{+}$ & 9.33 \\
\hline $\mathrm{Ca}^{+2}$ & 9.40 \\
\hline $\mathrm{Mg}^{+2}$ & 5.40 \\
\hline \multicolumn{2}{|c|}{ Available micronutrients (mg/kg) } \\
\hline $\mathrm{Fe}$ & 0.202 \\
\hline $\mathrm{Cu}$ & 0.145 \\
\hline Zn & 0.746 \\
\hline Mn & 1.335 \\
\hline
\end{tabular}


Table (2): Some chemical properties of the used organic materials

\begin{tabular}{|c|c|c|c|}
\hline \multirow{2}{*}{$\begin{array}{l}\text { Chemical } \\
\text { property }\end{array}$} & \multicolumn{3}{|c|}{ organic materials } \\
\hline & Olive waste & compost & Lemon waste \\
\hline $\mathrm{pH}(1: 2)$ & 5.6 & 7.02 & 3.26 \\
\hline$E C(d S / m), 1: 2$ & 7.3 & 7.10 & 7.20 \\
\hline O C (\%) & 40.7 & 17.4 & 86.0 \\
\hline Total N (\%) & 5.16 & 5.32 & 6.68 \\
\hline Total P (\%) & 0.042 & 0.013 & 0.044 \\
\hline \multicolumn{4}{|c|}{ Soluble cations (mg/kg) } \\
\hline $\mathrm{K}^{+}$ & 38.7 & 23.5 & 40.7 \\
\hline $\mathrm{Na}^{+}$ & 22.5 & 27.5 & 15.0 \\
\hline $\mathrm{Ca}^{+2}$ & 24. 0 & 16. 0 & 14.0 \\
\hline $\mathrm{Mg}^{+2}$ & 7.80 & 4.0 & 2.30 \\
\hline \multicolumn{4}{|c|}{ Soluble anions (mg/kg) } \\
\hline $\mathrm{SO}_{4}=$ & 40.5 & 49.11 & 51.25 \\
\hline $\mathrm{Cl}^{-}$ & 20. 0 & 22. 0 & 21. 0 \\
\hline \multicolumn{4}{|c|}{ Available micronutrients (mg/kg) } \\
\hline $\mathbf{F e}$ & 0.427 & 2.634 & 1.923 \\
\hline $\mathrm{Zn}$ & 2.500 & 3.146 & 1.079 \\
\hline $\mathrm{Cu}$ & 0.006 & 0.226 & 0.437 \\
\hline Mn & 0.180 & 3.284 & 0.600 \\
\hline
\end{tabular}

\section{RESULTS AND DISCUSSION}

Soil pH: Table (3) showed a significant effect of organic material type at each time of sampling, on the soil pH except at the second time of sampling.

Table (4) indicated a significant effect by decrease as results of present of organic material, whether with respect to the type or the rate and their interaction, except at the second time of sampling on soil $\mathrm{pH}$. The decreases in $\mathrm{pH}$ were noted with increasing time of sampling. The fourth time of sampling was significant lower soil $\mathrm{pH}$.

Table (4) showed also significant effects of the different organic materials on soil $\mathrm{pH}$ all incubation periods, except at the second time of sampling for $\mathrm{pH}$.

The lowest value of $\mathrm{pH}$ (averaged 7.32) was recorded at the fourth time of sampling with olive waste. Soil $\mathrm{pH}$ has decreased slightly due to the acidity indicated by the disposal of raw olive waste. It can be concluded, therefore, that due to the carbonate content of the soil, the surface application of olive waste does not markedly affect soil pH (Mechri et al., 2007). 
Regarding to the effect of organic material rate on soil $\mathrm{pH}$, the data presented in (Table 4) indicated that the rate of organic material has significant effect on $\mathrm{pH}$ at each time of sampling, except at that of the second time. Decreasing $\mathrm{pH}$ values with increasing rate of organic material were observed at each time of sampling and with increasing time of incubation. These results are agree with those obtained by Hossien (2008), Claudia et al. (2012) and Kavvadias et al. (2012).

The interaction effect of organic waste types and rate of application the results showed significant decreased of soil $\mathrm{pH}$, except at the second time of sampling (Table 3 ). The highest value of soil $\mathrm{pH}$ was observed at the first time of sampling without organic material (8.05). On the other hand, the lowest values of $\mathrm{pH}$ were found at the fourth time of sampling using $2 \%$ olive waste $(\mathrm{pH}=7.01)$. 
Table (3): soil $\mathrm{pH}$ as affected by type and rate of organic materials and incubation periods

\begin{tabular}{|c|c|c|c|c|c|}
\hline \multicolumn{2}{|c|}{ Organic material } & \multicolumn{4}{|c|}{ Time of Soil Sampling } \\
\hline Type & Rate, \% & $1^{\text {st }}$ time & $2^{\text {nd }}$ time & $3^{\text {rd }}$ time & $4^{\text {th }}$ time \\
\hline \multirow{5}{*}{ 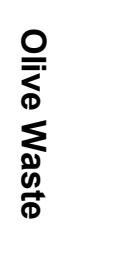 } & 0.0 & 8.05 & 8.00 & 7.80 & 7.79 \\
\hline & 0.5 & 8.00 & 7.94 & 7.65 & 7.40 \\
\hline & 1.0 & 7.94 & 7.91 & 7.60 & 7.26 \\
\hline & 1.5 & 7.89 & 7.80 & 7.52 & 7.16 \\
\hline & 2.0 & 7.80 & 7.76 & 7.04 & 7.01 \\
\hline \multirow{5}{*}{ 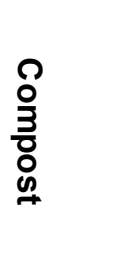 } & 0.0 & 8.05 & 7.80 & 7.80 & 7.79 \\
\hline & 0.5 & 8.00 & 7.98 & 7.71 & 7.50 \\
\hline & 1.0 & 7.96 & 7.90 & 7.60 & 7.31 \\
\hline & 1.5 & 7.92 & 7.80 & 7.55 & 7.12 \\
\hline & 2.0 & 7.90 & 7.78 & 7.25 & 7.09 \\
\hline \multirow{5}{*}{ 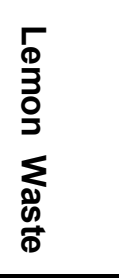 } & 0.0 & 8.05 & 8.00 & 7.80 & 7.79 \\
\hline & 0.5 & 7.96 & 7.90 & 7.63 & 7.54 \\
\hline & 1.0 & 7.87 & 7.80 & 7.56 & 7.25 \\
\hline & 1.5 & 7.73 & 7.69 & 7.40 & 7.12 \\
\hline & 2.0 & 7.70 & 7.50 & 7.15 & 7.07 \\
\hline \multicolumn{6}{|c|}{ Statistical significance $\left(\mathrm{LSD}_{0.05}\right)$} \\
\hline \multicolumn{2}{|c|}{ O.M type (M) } & $1.65 \mathrm{E}-07$ & $\mathrm{~N}$ & $9.53 \mathrm{E}-08$ & 0.032 \\
\hline \multicolumn{2}{|c|}{ Rate of O.M (R) } & $2.13 E-07$ & $\mathrm{~N}$ & $1.23 \mathrm{E}-07$ & 0.042 \\
\hline \multicolumn{2}{|c|}{$\mathbf{M} \times \mathbf{R}$} & 0.412 & $\mathrm{~N}$ & $2.38 \mathrm{E}-08$ & 8.348E-3 \\
\hline
\end{tabular}


Table (4): Mean values of soil $\mathrm{pH}$ at each time of sampling as affected by the type and rate of organic materials

\begin{tabular}{|c|c|c|c|c|}
\hline \multirow[b]{2}{*}{ Treatments } & \multicolumn{4}{|c|}{ Time of Sampling } \\
\hline & $1^{\text {st }}$ time & $2^{\text {nd }}$ time & $3^{\text {rd }}$ time & $4^{\text {th }}$ time \\
\hline \multicolumn{5}{|c|}{ Organic material type } \\
\hline Olive Waste & 7.80 & 7.76 & 7.04 & 7.01 \\
\hline Compost & 7.90 & 7.78 & 7.25 & 7.09 \\
\hline Lemon Waste & 7.70 & 7.50 & 7.15 & 7.07 \\
\hline $\operatorname{LSD}_{0.05}$ & $1.65 \mathrm{E}-07$ & $\mathrm{~N}$ & 9.53E-08 & 0.03 \\
\hline \multicolumn{5}{|c|}{ Rate of organic material, $\%$} \\
\hline 0.0 & 8.05 & 7.93 & 7.89 & 7.79 \\
\hline 0.5 & 7.99 & 7.94 & 7.66 & 7.48 \\
\hline 1.0 & 7.92 & 7.87 & 7.59 & 7.27 \\
\hline 1.5 & 7.85 & 7.76 & 7.49 & 7.13 \\
\hline 2.0 & 7.80 & 7.68 & 7.15 & 7.06 \\
\hline LSD $_{0.05}$ & 2.13E-07 & $\mathrm{N}$ & 1.23E-07 & 0.04 \\
\hline
\end{tabular}

\section{Available Trace Elements in soil:}

Table (5) showed that the organic material types, rates of application and their interactions significantly influenced the amounts of available $\mathrm{Fe}, \mathrm{Cu}, \mathrm{Zn}$ and $\mathrm{Mn}$ in soil at all time of samplings, except those of available $\mathrm{Cu}$ at the fourth time of sampling and available $\mathrm{Zn}$ at the first and third time of sampling. Also, the means of available $\mathrm{Fe}, \mathrm{Cu}, \mathrm{Zn}$ and $\mathrm{Mn}$ (Table 6) showed that the compost gave the highest values of available $\mathrm{Fe}, \mathrm{Mn}$ and $\mathrm{Zn}$ at the fourth time of sampling $(5.41,22.04$ and $5.02 \mathrm{mg} / \mathrm{kg}$ soil, respectively). However, the olive waste gave the highest value of available $\mathrm{Cu}(5.11 \mathrm{mg} / \mathrm{kg}$ soil) at the fourth time of sampling and the lemon waste gave the lowest value of available $\mathrm{Zn}$ at the first time of sampling (1.80 $\mathrm{mg} / \mathrm{kg}$ soil). It is also leas that, the olive waste gave the lowest value of available Fe and $\mathrm{Mn}$ at the first time of sampling $(0.67$ and $16.32 \mathrm{mg} / \mathrm{kg}$ soil, respectively), while the compost gave the lowest value of available $\mathrm{Cu}$ at the first time of sampling $(1.30 \mathrm{mg} / \mathrm{kg}$ soil).

Generally, the amounts of available $\mathrm{Fe}, \mathrm{Cu}, \mathrm{Mn}$ and $\mathrm{Zn}$ were increased with increasing organic material application rates and increasing time of sampling (Table 5). The highest values of available Fe $(6.16 \mathrm{mg} / \mathrm{kg}$ soil), Zn $(6.21 \mathrm{mg} / \mathrm{kg}$ soil), $\mathrm{Mn}(23.87 \mathrm{mg} / \mathrm{kg}$ soil) and $\mathrm{Cu}(6.71 \mathrm{mg} / \mathrm{kg}$ soil) were recorded for $2 \%$ organic materials rate at the fourth time of sampling. The increases of available micronutrients could be explained by the production of $\mathrm{CO}_{2}$ and forming $\mathrm{H}_{2} \mathrm{CO}_{3}$ during organic material decomposing. Nader et al. (2008) reported that the 
solubility increased of micronutrients in the soil may be due to lowering $\mathrm{pH}$ and air water balance. The compost applied causes high amount of O.M, and its oxidation and degradation would increase the micronutrients availability in soil (Gallardo-lara and Nogales, 1987). Increasing concentrations of $\mathrm{Zn}$ and Fe after organic waste application were also reported by Ageel and Hamed (2007). According to Piotrowska et al. (2006), the increase of extractable Fe can be attributed to the fact that this metal catalyze the oxidative transformation of phenols present in soil.

The interaction between organic waste type and rates of application had significant effect on the amounts of available $\mathrm{Fe}, \mathrm{Cu}, \mathrm{Zn}$ and $\mathrm{Mn}$ at all time of sampling, except available $\mathrm{Cu}$ at fourth time of sampling and $\mathrm{Zn}$ at first and third sampling, (Table 5). The highest values of available $\mathrm{Fe}, \mathrm{Zn}$ and $\mathrm{Mn}$ were obtained at the fourth time of sampling with $2 \%$ compost $(7.10,7.44$ and 24.88 $\mathrm{mg} / \mathrm{kg}$ soil, respectively). On the other hand, the highest value of available $\mathrm{Cu}$ was obtained at the fourth time of sampling with $2 \%$ olive waste $(7.45 \mathrm{mg} / \mathrm{kg}$ soil). However, the lowest values of available $\mathrm{Fe}, \mathrm{Cu}, \mathrm{Zn}$ and $\mathrm{Mn}$ were obtained at the first time of sampling without organic materials.

Table (7) showed regression equations for the relation between the available $\mathrm{Fe}\left(\mathrm{Y}_{1}\right)$, $\mathrm{Cu}\left(\mathrm{Y}_{2}\right), \mathrm{Zn}\left(\mathrm{Y}_{3}\right)$ and $\mathrm{Mn}\left(\mathrm{Y}_{4}\right)$ and the organic material rate $(\mathrm{X})$. 


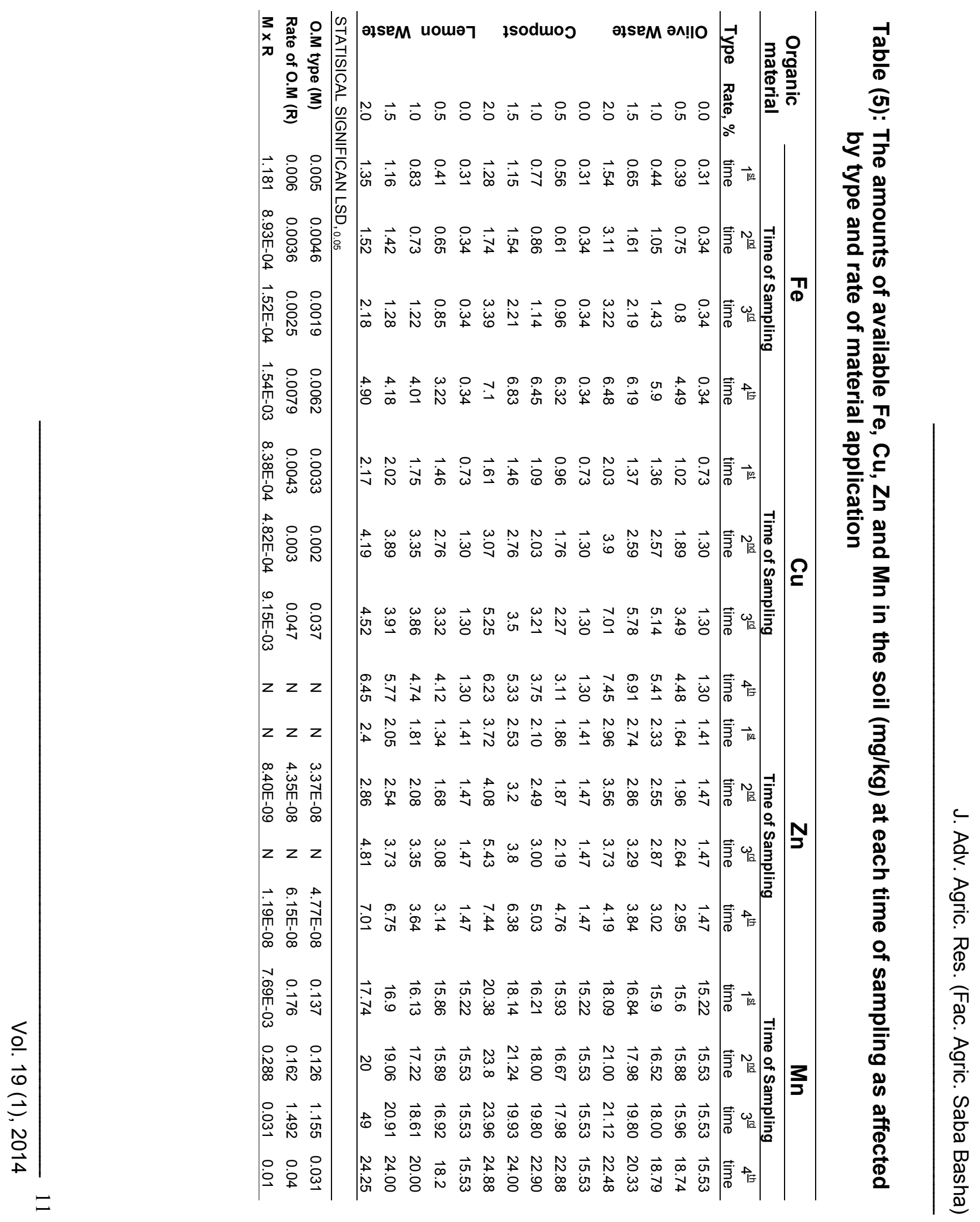




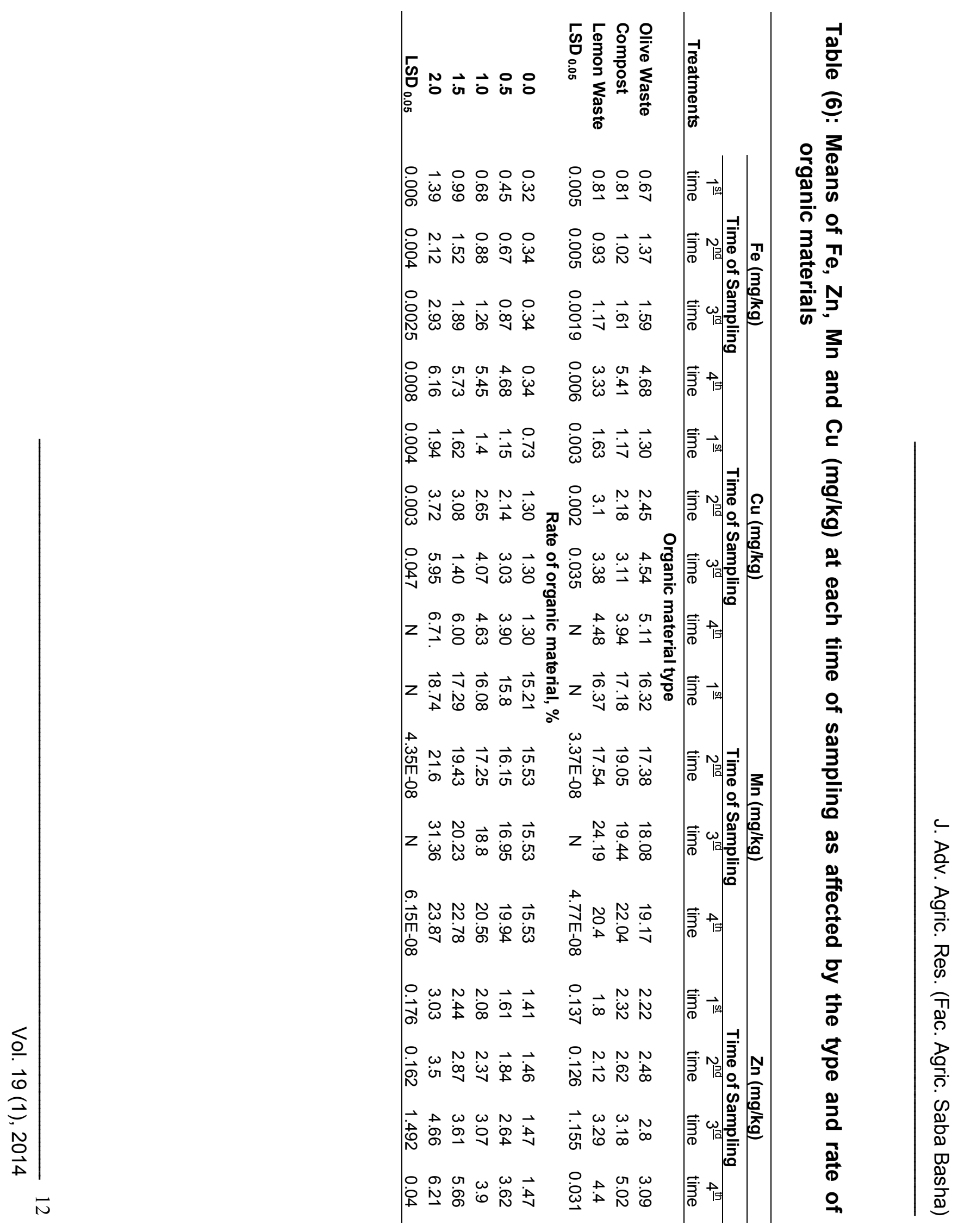


A specific relationship was found between $\mathrm{Fe}, \mathrm{Cu}, \mathrm{Zn}$ or $\mathrm{Mn}$ and organic material rate for the three materials at the first or fourth time of sampling. The comparison of the slopes of $\mathrm{Fe}, \mathrm{Cu}, \mathrm{Zn}$ and $\mathrm{Mn}$ regression equations gives a quantitative expression of the efficiency of organic waste rates for each organic material type. The comparison of slopes at the first time of sampling and at the fourth time of sampling with olive waste for Fe showed that, the efficiency of organic material rates was $513.97 \%$, while for $\mathrm{Zn}$, the efficiency was $150.71 \%$. On the other hand, with olive waste for $\mathrm{Cu}$, the efficiency of organic material rates were 499.32 $\%$, but for Mn, the efficiency of organic material rates was $221.92 \%$.

The comparison of slopes at the first time of sampling and at the fourth time of sampling with compost for Fe showed that, the efficiency of organic material rates were $554.55 \%$, while for $\mathrm{Zn}$, the efficiency of organic material rates were $362.07 \%$. On the other hand, the efficiency of organic waste rates was $534.51 \%$ for $\mathrm{Cu}$, but the efficiency of organic material rates was $158.18 \%$ for $\mathrm{Mn}$. The comparison of the slopes at the first time of sampling and at the fourth time of sampling with lemon waste for Fe; the efficiency of organic material rate was $356.18 \%$, while for $\mathrm{Zn}$, the efficiency was $546.1 \%$. On the other hand for $\mathrm{Cu}$, the efficiency of organic material rate was $347.38 \%$, but the efficiency of organic material rate was $53.28 \%$ for $\mathrm{Mn}$.

\section{Conclusion:}

The application of compost increased the amounts of DTPA- extractable Fe, $\mathrm{Mn}$ and $\mathrm{Zn}$ with different degrees. The concentrations of micro elements in the present study were higher after 16 weeks of incubation than in the first period of incubation, probably due to degradation of the organic materials and release of metals, which were complexes with organic matter at the beginning of incubation. Organic matter content and the $\mathrm{pH}$ value of the soil are relatively easy to change due the application of the organic waste materials. Therefore, the effect of organic matter and $\mathrm{pH}$ on the extractability of micro elements deserves special attention. 


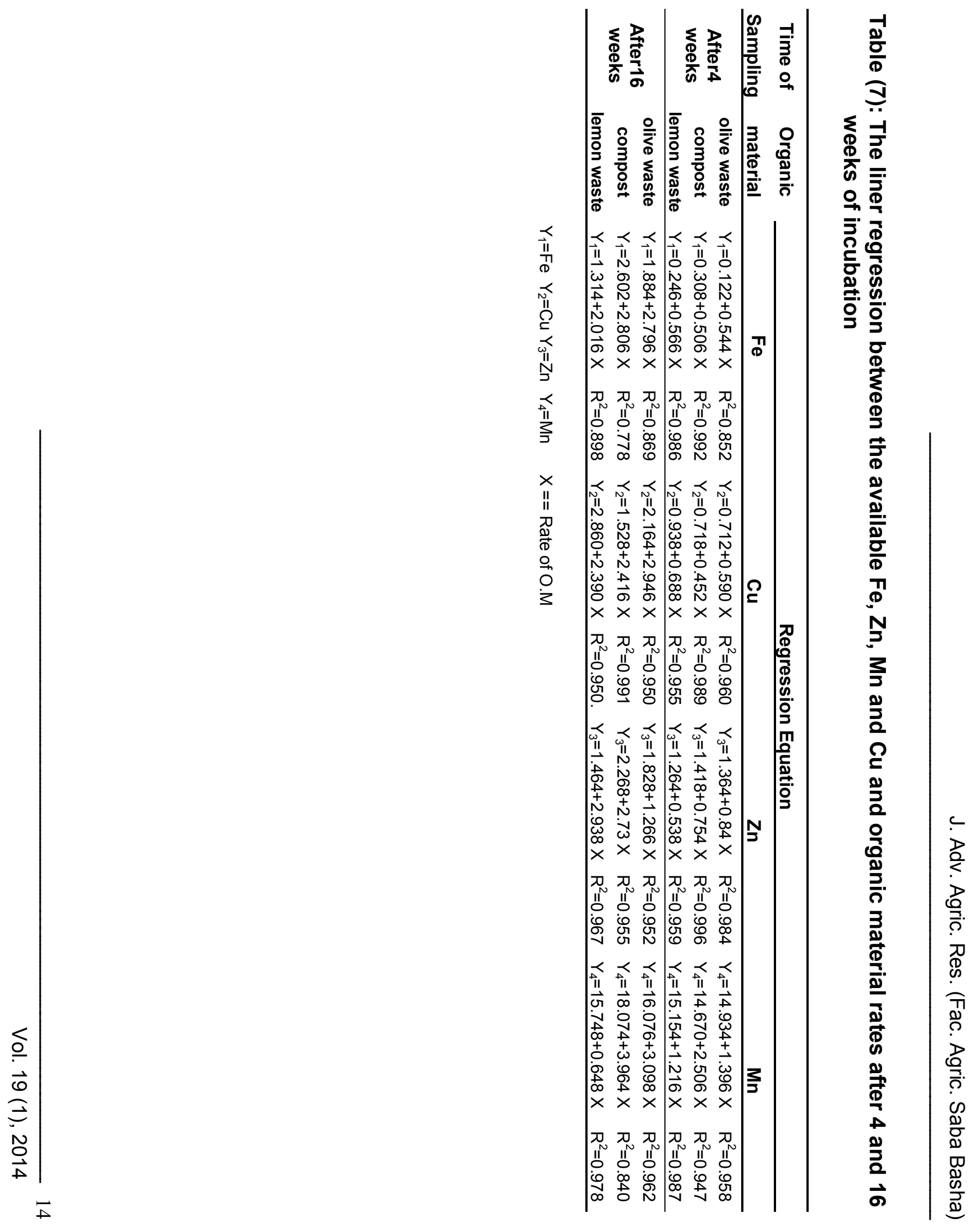




\section{REFERENCES}

Ageel, A. M. and K. M. Hameed. 2007. Implementation of olive mill by products in agriculture. World J. Agric. Sci., 3: 380-385.

Arnesen, A. K. M. and B. R. Singh. 1999. Plant uptake and DTPA-extractability of $\mathrm{Cd}, \mathrm{Cu}, \mathrm{Ni}$ and $\mathrm{Zn}$ in a Norwegian alum shale soil as affected by previous addition of dairy and pig manures and peat. Can. J. Soil Sci., $531-539$.

Baran, W. 2001. The effect of grape marc as growing medium on growth of hypostases plant. Bioresour. Technol., 78: 103-106.

Black, C. A. A. 1965. Methods of Soil Analysis. Am. Soc. Agron. Madison, Wisconsin. USA.

Bloomfield, C. and G. Pruden. 1975. The effect of aerobic and anaerobic incubation on exchangeabilities of heavy metals in digested sewage sludge. Environ.Pollut., 8:217-232.

Claudia, D. B., P. Elisa., D. Marta., S. Nicola and B. Enrico. 2012. Short- and long-term effects of olive mill wastewater land spreading on soil chemical and biological properties. Soil Bio and Bioch., Soil 1-10.

Del, C. P. W., J. Chardon and W. Salomons. 1993. Influence of cattle-manure slurry application on the solubility of $\mathrm{Cd}, \mathrm{Cu}$ and $\mathrm{Zn}$ in a manuared acidic, loamy sand soil. J. Environ, Qual., 22: 689-697.

Gallardo-lara, F and R. Nogales. 1987. Effect of the application of town refuses compost on the soil-plant system: a revew. Bio. Wastes, 19: 3561.

Gigliotti, G., D. Businelli, and P. L Giusquiani. 1996. Trace metals uptake and distribution in corn plants grown on a 6-year urban waste compost amended soil. Agric. Ecos. Environ., 58: (2/3) 199-206.

Gomez, K. and A. A. Gomez. 1984. Statistical of Procedures for Agricultural Research (2 Ed). An International Rice Research Institute Bok. A Wiley Interscience Publisher, New York.

Hamidpour, M., M. Afyuni., E. Khadivi., A. Zorpas and V. Inglezakis. 2012. Composted municipal waste effect on chosen properties of calcareous soil. Intern. Agrophysics, 26: 4, 365-374.

He, Q.B. and Singh, B.R. 1993. Effect of organic matter on the distribution, extractability and uptake of $\mathrm{Cd}$ in soils. J. Soil Sci., 44: $641-650$.

Hossien, A. G. 2008. Effect of Lemon Waste on Soil pH and Availability of Micronutrient in Calcareous Soils of Fars. International Meeting on Soil Fertility Land Management and Agroclimatology. p.449-452.

Jackson, M. L. 1973. Soil Chemical Analysis" Prentice Hall of India. Private Limited. New Delhi.

Kavvadias, V., M. Papadopoulodu and M. Doula. 2012. Olive oil mill waste application on soil: Effect on soil microbial activity and its relation to soil chemical properties. J. Agric. Sci., 182: 144-155. 
Krogstad, T. 1983. Effect of liming and decomposition on chemical composition, ion exchange and heavy metal ion selectivity in sphagnum peat. Scientific Reports of the Agricultural University of Norway Aas, Norway, p. 79.

Lindsay, W.L. and W. A. Novvell. 1978. Development of a DTPA soil test for Zn,Fe, Mn and Cu. Soil Sci. Soc. Amer. J., 42: 421-428.

Lo, K. S. L., W. F. Yang and Y.C Lin. 1992. Effects of organic matter on the specific adsorption of heavy metals by soil. Toxicol. Environ. Chem., 34: 139 - 153.

Lowther, J. R. 1980. Use of single $\mathrm{H}_{2} \mathrm{SO}_{4}-\mathrm{H}_{2} \mathrm{O}_{2}$ digest for the analysis of pins radiate needless. Commun Soil Sci. Plant Analysis, 11,11: 175-188.

Mechri, B., F. Attia., M. Braham., E. S Ben. and M. Hammami. 2007. Agronomic application of olive mill wastewaters with phosphate rock in a semi-arid Mediterranean soil modifies the soil properties and decreases the extractable soil phosphorus. J. Envir. Manag. 85: 1088-1093.

Nader, R. A. H., W. Amal., D. Abou El-Khair and N. Raafat. 2008. Effect of Organic and Bio-fertilizers on Phosphorus and Some Micronutrients Availability in a Calcareous Soil, Soil, Water and Environment Research Institute, Agriculture Research Center, Giza, Egypt. Res. J. Agric. Biol. Sci., 4(5): 545-552.

Page, A. L., R. H. Miller., and D. R. Keeney. 1982. Methods of Soil Analysis, Soci part 2: Chemical and Microbiological Properties, Ame Soci Agro,Madsison,Wisconsin. USA.

Piotrowska, A., G. lamarino., M. A. Rao and L. Gianfreda. 2006. Short term effects of olive mill waste water (OMW) on chemical and biochemical properties of a semiarid Mediterranean soil. Soil Biol. Bioch., 38: 600-610.

Romero. E., E. Benitez and R. Nogales. 2005. Suitability of wastes from oliveoil industry for initial reclamation of a $\mathrm{Pb} / \mathrm{Zn}$ mine tailing. J. Agric. Sci., 165: 153-165.

Sposito, G. 1989. The Chemistry of Soils .Oxford Univ. Press, New York, USA. Temminghoff, E. J. M., S. E. A. Van Der Zee and F. A. M Dehaan. 1998. Effects of dissolved organic matter on the mobility of copper in a contaminated sandy soil. Eur.J. Soil Sci., 49: 617-628. 


\section{الملخص العربى}

تأثير المخلفات العضوية وفترات التحضين على تيسر الحديد ، المنجنيز ، النحاس و الزنك فى أرض جيرية

\section{هاجر القذافى فرحات و ماجدة أبو المجد حسين و وفاء محمد على و هدى عبدالفتاح محمود}

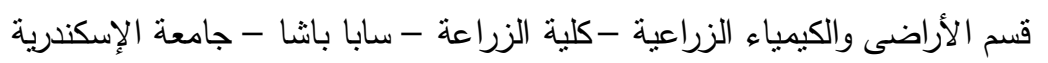

أجريت تجربة تحضين تربة جيرية لأربعة فترات ترواحت من 4 الى 16 أسبوع لدراسـة تأثير كل من

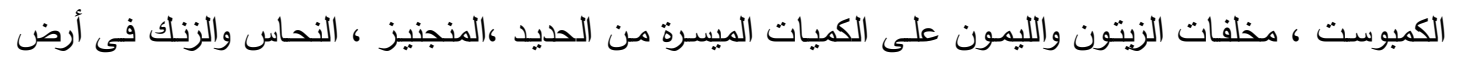

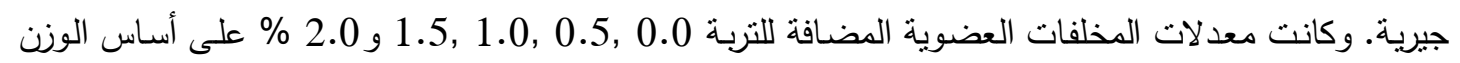
الجاف. ولقد أوضحت النتائج انخفاض فى pH تربة بزيادة معدل المواد العضوية عند كل فترة من فترات التحضين

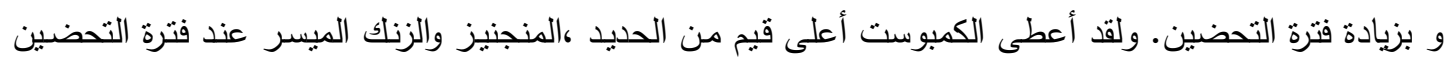
الرابعة (بعد 16 أسبوع) وكانت هذه القيم هى (5.02 ، 22.04 و 5.41 ملجرام/ كجم تربة ) على ألى التوالى.

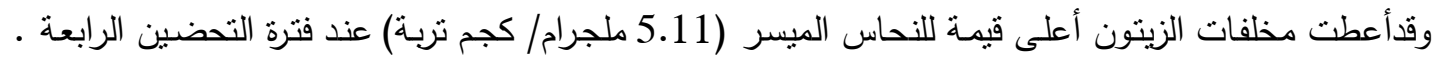
عامة فالحديد و المنجنيز و النحاس و الزنكك الميسر يزداد مع زيادة معدل اضافة المواد العضوية وبزيادة فترة

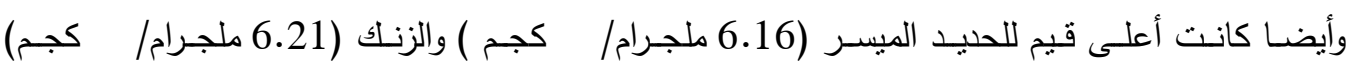

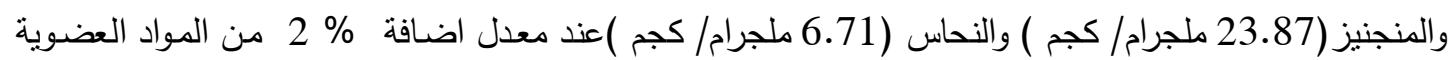
عند فترة التحضين الرابعة (16 أسبوع ). 